\title{
Analysis of the efficacy and safety of iodine-125 seeds implantation in the treatment of patients with inoperable early-stage non-small cell lung cancer
}

\author{
Enli Chen, BS', Juan Wang, MD², Hongtao Zhang, MD², Yuwei Zhang, MS', Chenfei Jia, BS', Xueya Min, BS', \\ Yansong Liang, MS ${ }^{2}$ \\ 'Graduate School of Hebei Medical University, Shijiazhuang, Hebei, China, ${ }^{2}$ Department of Oncology, Hebei General Hospital, \\ Shijiazhuang, Hebei, China
}

\begin{abstract}
Purpose: To evaluate the efficacy and safety of iodine-125 ( $\left.{ }^{125} \mathrm{I}\right)$ seeds implantation for inoperable early-stage nonsmall cell lung cancer (NSCLC).

Material and methods: PubMed, Cochrane Library, Embase, China Biology Medicine disc (CBM), China National Knowledge Infrastructure (CNKI), and Wanfang Data were searched from inception until April 2020. Data were collected concerning overall survival, short-term efficacy, and complications. Meta-analysis was performed using R software (version 3.6.3).

Results: Nine studies involving 308 patients were included. Meta-analysis showed that the 1-, 2-, and 3-year survival rates were $0.98 \%$ (95\% CI: $0.95-0.99 \%), 0.83 \%$ (95\% CI: $0.77-0.89 \%)$, and $0.65 \%$ (95\% CI: 0.55-0.75\%), respectively; short-term local control rate (LCR) and effective rates were $0.99 \%$ (95\% CI: 0.98-1.00\%) and 0.92\% (95\% CI: 0.83-0.98\%), respectively; 1-, 2-, and 3-year LCRs were 0.96\% (95\% CI: 0.83-1.00\%), 0.94\% (95\% CI: $0.85-0.99 \%)$, and 0.95\% (95\% CI: $0.76-1.00 \%)$, respectively. Sub-group analysis of the prescribed dose found that when the prescribed dose was $>120 \mathrm{~Gy}$, short-term efficacy and 1-year LCR were increased significantly $(p<0.01)$. The incidence of bleeding, pneumothorax, and radiation lung injury was $0.14 \%$ (95\% CI: $0.07-0.21 \%), 0.19 \%$ (95\% CI: $0.11-0.28 \%$ ), and $0.00 \%$ (95\% CI: $0.00-0.03 \%$ ), respectively. Two studies involving 106 patients compared ${ }^{125} \mathrm{I}$ seeds combined with chemotherapy versus chemotherapy alone for NSCLC. Results showed that compared with chemotherapy alone, ${ }^{125}$ I seeds combined with chemotherapy could improve short-term LCR $(\mathrm{RR}=1.34,95 \% \mathrm{CI}: 1.09-1.65 \%, p=0.005)$ and short-term effective rate $(\mathrm{RR}=1.49$, 95\% CI: $1.14-1.96 \%, p=0.004)$.

Conclusions: ${ }^{125} \mathrm{I}$ seeds implantation is safe and effective approach for the treatment of inoperable early-stage NSCLC, but high-quality clinical research is still needed to further confirm the findings.

J Contemp Brachytherapy 2021; 13, 3: 347-357 DOl: https://doi.org/10.5114/jcb.2021.106241
\end{abstract}

Key words: NSCLC, iodine-125, brachytherapy, meta-analysis.

\section{Purpose}

In recent years, due to rapidly growing aging population and lung cancer screening, early diagnosis rate of lung cancer has increased. Early-stage non-small cell lung cancer (NSCLC) accounts for approximately $25 \%$ of all lung cancer cases [1-3]. Lobectomy is the standard treatment for early NSCLC [4] and for patients with various comorbidities, such as chronic obstructive pulmonary disease and heart disease, with radiotherapy regarded as an alternative treatment [5]. Dose-escalation of traditional external radiation therapy is often limited by radiation tolerance of normal lung tissues and adjacent vital or- gans, including esophagus, spinal cord, etc., which leads to the fact that the target dose can hardly reach more than 70 Gy. Many studies have indicated that stereotactic body radiotherapy (SBRT) is a well-established treatment option for medically inoperable patients with early-stage NSCLC, and can achieve satisfactory local control. Nagata et al. [6] treated 100 inoperable early-stage NSCLC patients with SBRT with a prescribed dose of 48 Gy in 4 fractions over 4-8 days. The 3- and 5-year survival rates were $59.9 \%$ and $42.8 \%$, respectively, and the 3 -year local control rate (LCR) was $52.8 \%$. Dupic et al. [7] published a prospective study of 100 patients who received treatment for inoperable early-stage NSCLC, with prescribed
Address for correspondence: Juan Wang, Department of Oncology, Hebei General Hospital, 348 West Heping Road, Shijiazhuang, Hebei, 050051, China, phone: +86 0311-85988741, ๑-mail: lizizhiruhb@163.com
Received: 28.08 .2020

Accepted: 24.02 .2021

Published: 18.05.2021 
dose of 54 Gy in 3 fractions for 76 patients and 50 Gy in 5 fractions for 24 patients. The 1-, 2-, 3-, and 5-year LCRs were $100 \%, 98.2 \%, 98.2 \%$, and $77.7 \%$, respectively, and survival rates were $83 \%, 71.2 \%, 58.1 \%$, and $33.2 \%$, respectively. Shu et al. [8] treated 68 early-stage NSCLC patients aged $\geq 75$ years with SBRT. The 1-, 3-, and 5-year survival rates were $92.6 \%, 77.2 \%$, and $59.1 \%$, respectively, and the $1-, 3-$, and 5-year LCRs were $95.6 \%, 88.9 \%$, and $85.6 \%$, respectively. However, for central lung cancer close to the trachea, esophagus, and spinal cord, and also for peripheral lung cancer close to the chest wall and brachial plexus, there is still a great controversy concerning the dose and exposure range of SBRT in the treatment of earlystage NSCLC.

Radioactive ${ }^{125}$ I seeds can reduce the dose around the target area rapidly while delivering a high-dose to the target area, which has a high target conformity. It slowly and continuously releases low-dose $\gamma$-rays and directly acts on DNA of tumor cells to cause tumor cell apoptosis. Chen et al. [9] treated 28 patients with locally advanced NSCLC, in whom concurrent chemoradiotherapy had failed with ${ }^{125} \mathrm{I}$ seeds implantation therapy combined with bronchial arterial chemoembolization. The results showed that 6-month disease control rate reached $92.86 \%$, and median progression-free survival was achieved in 8 months. In addition, meta-analysis results of Zhang et al. [10] showed that ${ }^{125} \mathrm{I}$ seeds brachytherapy alone could significantly improve clinical efficacy of patients with advanced NSCLC compared with chemotherapy. All of these studies confirmed that ${ }^{125}$ I seeds brachytherapy is an effective and safe approach for the treatment of NSCLC. On the other hand, for small tumor volume in early-stage NSCLC, because the cost of ${ }^{125}$ I seeds therapy is positively correlated with the size of lesion, its overall medical cost is significantly lower than SBRT.

Due to characteristics of lesser damage, satisfactory efficacy, and relatively lower cost, ${ }^{125}$ I seeds had been widely used in the treatment of early-stage lung cancer. Li et al. [11] treated 24 early-stage NSCLC patients with ${ }^{125}$ I seeds implantation under computed tomography (CT) guidance, with a prescription dose of 100-120 Gy. The results showed the LCR of $78.3 \%$ and the 1-, 2-, and 3 -year survival rates of $95.8 \%, 78 \%$, and $55 \%$, respectively. Huo et al. [12] treated 21 early-stage NSCLC patients with ${ }^{125}$ I seeds under CT guidance combined with template, and a prescription dose was 120-160 Gy. Their findings revealed a 3-year LCR of 95.2\% and 3-year survival rate of $72.9 \%$, which was comparable to SBRT in the treatment of early-stage inoperable NSCLC in recent years. The occurrence of adverse events was significantly reduced, and no treatment-related adverse reactions of grade 3 or higher or deaths occurred during follow-up period. A number of studies $[13,14]$ have shown that ${ }^{125}$ I seeds had a favorable therapeutic effect in NSCLC. However, studies following the principles of evidence-based medicine (EBM) are lacking to evaluate the efficacy and safety of ${ }^{125} \mathrm{I}$ seeds in the treatment of early-stage NSCLC. Therefore, we conducted a systematic review and meta-analysis to assess clinical efficacy and safety of ${ }^{125} \mathrm{I}$ seeds for early-stage NSCLC.

\section{Material and methods}

\section{Literature search}

PubMed, Cochrane Library, Embase, China Biology Medicine disc (CBM), China National Knowledge Infrastructure (CNKI), and Wanfang Data were searched to identify relevant studies published up till April 2020 without language restrictions. Main keywords used for the search included "I ${ }^{125}$ OR ${ }^{125} \mathrm{I}$ OR iodine-125", "lung cancer OR NSCLC", and "early-stage OR I OR II".

\section{Inclusion and exclusion criteria for studies}

The following inclusion criteria were used for the literature: 1 . The study design was confined to randomized controlled trials, cohort studies, or single-arm studies; 2. Patients received ${ }^{125} \mathrm{I}$ brachytherapy (or combined with chemotherapy) in the treatment group and chemotherapy alone in the control group for the treatment of early-stage NSCLC; 3. Patients had pathologically diagnosed stage I or II NSCLC, Karnofsky performance status $\geq 60$, time of survival $\geq 3$ months, no chemotherapy contraindication before treatment, and no significant abnormalities in the liver, kidney, and heart function; 4 . Studies had outcomes of response evaluation defined by response evaluation criteria in solid tumors [15].

The major exclusion criteria were: 1 . Animal experiments, review, and other irrelevant studies; 2 . No available data about primary outcomes; 3 . Patients with small cell lung cancer or stage III/IV NSCLC.

\section{Data extraction and quality assessment}

According to preferred reporting items for systematic reviews and meta-analysis statement, two reviewers (E.C and J.W) independently searched potentially relevant articles and conducted data extraction. Any disagreement between the two reviewers were resolved consensually by including a third reviewer (H.Z). The following items were collected from each study: publication details, demographic and clinical information, and outcome measures, such as efficacy and complications.

Randomized controlled trials (RCTs) were assessed according to the improved Jadad scale [16], including 4 aspects: generation of random sequences, allocation concealment, blind method, withdrawal, and drop out. Scores of 1 to 3 points were considered as low quality, and scores of 4 to 7 points as high quality.

Non-RCTs were assessed following Newcastle-Ottawa scale $[17,18]$, using selection of subjects (representativeness of exposed cohort, selection of non-exposed cohort, ascertaining exposure, and outcome not present at start of study), comparability of groups, and measurement of exposure (assessment of outcome, length of adequate follow-up, and sufficiency of follow-up). Based on the afore-mentioned criteria, a study was rated from 0 to 9 stars.

\section{Curative effects}

According to the response evaluation criteria in solid tumors, indicators consisted of complete response (CR), partial response (PR), stable disease (SD), and progressive 
disease (PD). Primary endpoints of our study were overall survival rate, effective rate (ER), which was defined as a proportion of patients with a response either as CR or $\mathrm{PR}[\mathrm{ER}=(\mathrm{CR}+\mathrm{PR}) /$ total $]$ and $\mathrm{LCR}$, defined as $\mathrm{CR}$ or PR, or $\mathrm{SD}[\mathrm{LCR}=(\mathrm{CR}+\mathrm{PR}+\mathrm{SD}) /$ total $]$. Short-term efficacy indicated an efficacy at 3 months after implantation.

\section{Statistical analysis}

Meta-analyses and forest plots were prepared in R software (version 3.6.3), using meta and forest plot packages [19]. Risk ratio (RR) was evaluated as a fundamental measurement of dichotomous data using Mantel-Haenszel method. $I^{2}$ statistic and $p$-value were used to test statistical heterogeneity of studies involved. We chose a fixed-effects method with a predefined significance threshold of $I^{2}<50 \%$ or $p>0.1$, otherwise a random-effect method was used. A sensitivity analysis was performed to identify whether the results were stable, and a sub-group analysis was performed to determine source of heterogeneity. A $p$-value of $<0.05$ was considered statistically significant. Publication bias was tested by funnel plots.

\section{Results}

\section{Literature search results}

The process of literature search was summarized in Figure 1, and a total of 211 records, including 28 published in English (14 in PubMed, 1 in Cochrane library, and 13 in Embase) and 183 in Chinese (28 in CBM, 61 in CNKI, and 94 in Wanfang Data) were identified during the initial literature search. Of these, 84 duplicates were removed, and 127 remained. According to the literature inclusion and exclusion criteria, 108 studies were excluded after reading the titles and abstracts of the literature, and 19 were left. After reading the full text, 10 studies were excluded, with 6 studies on some diseases other than early NSCLCs, 2 dosimetric studies, 1 study without clear clinical stage, and 1 study involving other radiotherapy techniques. Nine studies involving 308 patients were finally included, and all were from China. Among them, there were 2 RCTs on ${ }^{125}$ I seeds plus chemotherapy versus chemotherapy alone for early NSCLC, there was one RCT on ${ }^{125}$ I seeds versus chemotherapy for early NSCLC, and there were 6 single-arm retrospective cohort studies on ${ }^{125}$ I seeds for early NSCLC. The basic characteristics of the included literature are shown in Tables 1-2 [11-14, 20-24].

\section{Quality of the studies included}

Studies by Fu et al. [22] and Yang et al. [23] were of high quality, whereas a study by Lin et al. [24] was of low quality; six single-arm studies were evaluated using Newcastle-Ottawa scale, and all obtained a score of 5 to 6 (Tables 3-4).

\section{Meta-analysis results \\ ${ }^{125}$ I seeds implantation in the treatment of early NSCLC}

Six studies [11-13, 20-22] described survival of patients after ${ }^{125}$ I seeds implantation. There was no statisti-

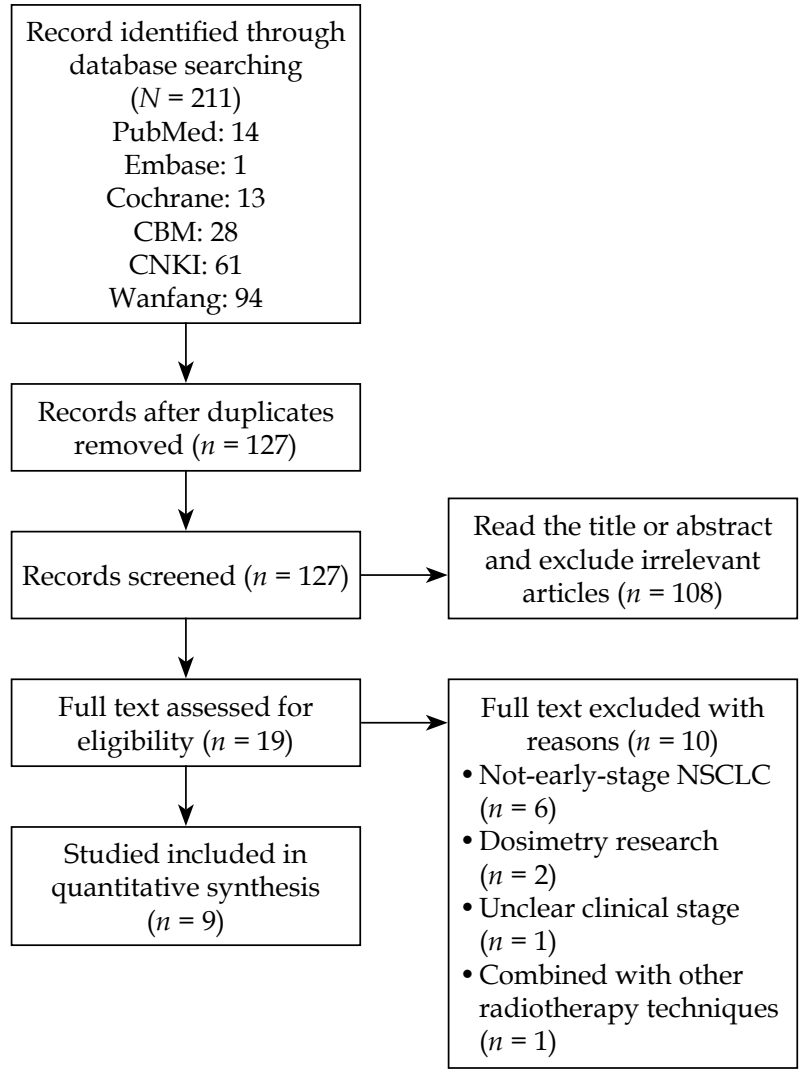

Fig. 1. Flow diagram of the study selection process. CBM - China Biology Medicine disc, CNKI - China Knowledge Resource Integrated Database

cal heterogeneity between the studies $\left(I^{2} \leq 50 \%, p \geq 0.1\right)$, and fixed-effect model was used. The results showed that the 1-, 2-, and 3-year survival rates were $0.98 \%$ (95\% CI: $0.95-0.99 \%), 0.83 \%$ (95\% CI: $0.77-0.89 \%)$, and $0.65 \%$ (95\% CI: $0.55-0.75 \%$ ), respectively (Figure 2 ).

Seven studies [11-14, 20, 21, 24] reported short-term LCR after ${ }^{125} \mathrm{I}$ seeds implantation. There was no statistical heterogeneity among the results of these studies $\left(I^{2}=22 \%, p=0.26\right)$, showing short-term LCR as $0.99 \%$ (95\% CI: $0.98-1.00 \%)$. Seven studies [11-14, 20, 21, 24] described short-term effective rate, and there was a statistical heterogeneity among the results of the studies $\left(I^{2}=69 \%, p=0.01\right)$. A random effect model was applied for meta-analysis, indicating a result of $0.92 \%$ (95\% CI: 0.83$0.98 \%$ ). Further sub-group analysis of the prescribed dose found that when prescribed dose was > $120 \mathrm{~Gy}$, shortterm effective rate was increased significantly (Figure 3 ).

Four studies [12, 13, 21, 22] presented LCR. Among them, the 1-year LCR was statistically heterogeneous $\left(I^{2}=83 \%, p<0.01\right)$. A meta-analysis using random effect model showed a result of $0.96 \%$ (95\% CI: $0.83-1.00 \%)$. Additional sub-group analysis of the 1-year LCR found that the LCR of the group with a prescription dose > 120 Gy was significantly increased (Figure 4B). There was no statistical heterogeneity in the 2- and 3-year LCRs $\left(I^{2} \leq 50 \%\right.$, $p \geq 0.1$ ). Fixed-effect model was used for meta-analysis, and the results showed that the 2- and 3-year LCRs were $0.94 \%$ (95\% CI: $0.85-0.99 \%$ ) and $0.95 \%$ (95\% CI: $0.76-$ $1.00 \%)$, respectively (Figure 4). 
Table 1. Characteristics of the included studies

\begin{tabular}{|c|c|c|c|c|c|c|c|c|c|c|}
\hline $\begin{array}{l}\text { Study, } \\
\text { year [ref.] }\end{array}$ & Design & $\begin{array}{c}\text { Publica- } \\
\text { tion }\end{array}$ & $\mathrm{T} / \mathrm{C}$ & Age (y) & $\begin{array}{l}\text { Male/ } \\
\text { female }\end{array}$ & $\begin{array}{l}\text { Tumor } \\
\text { stage }\end{array}$ & $\begin{array}{l}\text { Tumor } \\
\text { size }\end{array}$ & $\begin{array}{c}\text { Tumor } \\
\text { location }\end{array}$ & $\mathrm{T}$ (dose)/C & $\begin{array}{r}\text { Follow-up } \\
\text { (months) }\end{array}$ \\
\hline $\begin{array}{l}\text { Jiakai Li, } \\
2013 \text { [11] }\end{array}$ & $\begin{array}{l}\text { Retro- } \\
\text { spective } \\
\text { study }\end{array}$ & $\begin{array}{c}\text { Mol Clinl } \\
\text { Oncol }\end{array}$ & $\begin{array}{c}24(28 \\
\text { lesions } / 0\end{array}$ & $\begin{array}{c}\text { Mean, } \\
65.4 \\
(54-81) \\
\end{array}$ & $18 / 6$ & $T_{1-3} N_{0} M_{0}$ & $4.0 \pm 1.5$ & N.A. & $\begin{array}{c}125 \mid \\
(100-120 \mathrm{~Gy}) / \\
-\end{array}$ & $\begin{array}{c}\text { Median, } \\
31.5 \\
(8-46)\end{array}$ \\
\hline $\begin{array}{l}\text { Bin Huo, } \\
2017 \\
{[12]}\end{array}$ & $\begin{array}{l}\text { Retro- } \\
\text { spective } \\
\text { study }\end{array}$ & $\begin{array}{l}\text { Chin J Ra- } \\
\text { diol Med } \\
\text { Prot }\end{array}$ & $21 / 0$ & $\begin{array}{c}\text { Median, } \\
69 \\
(58-80)\end{array}$ & $15 / 6$ & $\mathrm{~T}_{1-2} \mathrm{~N}_{0} \mathrm{M}_{0}$ & $\begin{array}{c}\geq 3 \mathrm{~cm}: \\
n=6 \\
<3 \mathrm{~cm}: \\
n=15\end{array}$ & $\begin{array}{c}\text { P: } 19, \\
\text { Central: } 2\end{array}$ & $\begin{array}{c}125 \mid \\
(120-160 \text { Gy }) / \\
-\end{array}$ & $\begin{array}{c}\text { Median, } \\
25.1 \\
(4.4-72.7)\end{array}$ \\
\hline $\begin{array}{l}\text { Jingkui } \\
\text { Yang, } \\
2014 \text { [13] }\end{array}$ & $\begin{array}{l}\text { Retro- } \\
\text { spective } \\
\text { study }\end{array}$ & $\begin{array}{c}\text { Chin J Clin } \\
\text { Oncol }\end{array}$ & $48 / 0$ & $67.9 \pm 8.6$ & $35 / 13$ & $|-| \mid\left(N_{0}\right)$ & $\begin{array}{c}\text { Median, } \\
2.1 \mathrm{~cm} \\
(0.7-3.0)\end{array}$ & $P$ & $\begin{array}{c}125 \mid \\
(110 \text { Gy }) /-\end{array}$ & N.A. \\
\hline $\begin{array}{l}\text { Mingyao } \\
\text { Ke, } 2011 \\
{[14]}\end{array}$ & $\begin{array}{l}\text { Retro- } \\
\text { spective } \\
\text { study }\end{array}$ & $\begin{array}{l}\text { Chin } \\
\text { J Radiat } \\
\text { Oncol }\end{array}$ & $16 / 0$ & $\begin{array}{c}\text { Median, } \\
74 \\
(70-82)\end{array}$ & $11 / 5$ & I & $\begin{array}{c}>3 \mathrm{~cm}: \\
n=3 \\
\leq 3 \mathrm{~cm}: \\
n=13\end{array}$ & $P$ & $\begin{array}{c}125 \mid \\
(140-160 \mathrm{~Gy}) / \\
-\end{array}$ & $\begin{array}{c}\text { Mean, } \\
35(10-56)\end{array}$ \\
\hline $\begin{array}{l}\text { Jingkui } \\
\text { Yang, } \\
2014 \text { [20] }\end{array}$ & $\begin{array}{l}\text { Retro- } \\
\text { spective } \\
\text { study }\end{array}$ & $\begin{array}{l}\text { Chin } \\
\text { J Geriat- } \\
\text { rics }\end{array}$ & $18 / 0$ & $\begin{array}{c}\text { Median, } \\
73.7 \\
(60-89) \\
\end{array}$ & $12 / 6$ & $I-I I\left(N_{0}\right)$ & $\begin{array}{l}\text { Median, } \\
2.1 \mathrm{~cm} \\
(0.7-3.0)\end{array}$ & N.A. & $\begin{array}{c}125 \mid \\
(110 \text { Gy }) /-\end{array}$ & N.A. \\
\hline $\begin{array}{l}\text { Hua } \\
\text { Cheng, } \\
2019 \text { [21] }\end{array}$ & $\begin{array}{l}\text { Retro- } \\
\text { spective } \\
\text { study }\end{array}$ & $\begin{array}{c}\text { World } \\
\text { Latest } \\
\text { Medicine } \\
\text { Informa- } \\
\text { tion }\end{array}$ & $26 / 0$ & $\begin{array}{c}\text { Median, } \\
68.5 \\
(50-89)\end{array}$ & $15 / 11$ & $\mathrm{~T}_{1-3} \mathrm{~N}_{0} \mathrm{M}_{0}$ & $\begin{array}{l}\text { Median, } \\
2.6 \mathrm{~cm} \\
(1.2-5.0)\end{array}$ & N.A. & $\begin{array}{c}125 \mid \\
(100-120 \mathrm{~Gy}) / \\
-\end{array}$ & $\begin{array}{c}\text { Mean, } \\
41(10-50)\end{array}$ \\
\hline $\begin{array}{l}\text { Wei Fu, } \\
2019 \text { [22] }\end{array}$ & RCTs & $\begin{array}{l}\text { J Pract } \\
\text { Radiol }\end{array}$ & $25 / 24$ & $\begin{array}{c}\text { T: } 63.24 \\
\pm 1.27 \\
\text { C: } 63.18 \\
\pm 1.24\end{array}$ & $31 / 18$ & I-II $\left(\mathrm{N}_{0}\right)$ & $\begin{array}{c}\mathrm{T}: \geq 3 \mathrm{~cm}: \\
n=8 \\
<3 \mathrm{~cm}: \\
n=17 \\
\mathrm{C}: \geq 3 \mathrm{~cm}: \\
n=6 \\
<3 \mathrm{~cm}: \\
n=18\end{array}$ & $\begin{array}{c}\text { TP: 22, } \\
\text { Central: } 3 \text {, } \\
\text { CP: } 22 \text {, } \\
\text { Central: } 2\end{array}$ & $\begin{array}{c}125 \mid \\
(\text { N.A. }) / T P\end{array}$ & $\begin{array}{l}\text { T: Mean, } \\
14(6-24) \\
\text { C: Mean, } \\
13(7-24)\end{array}$ \\
\hline $\begin{array}{l}\text { Jianguo } \\
\text { Yang, } \\
2018 \text { [23] }\end{array}$ & RCTs & $\begin{array}{l}\text { Chinese } \\
\text { Journal of } \\
\text { Practical } \\
\text { Medicine }\end{array}$ & $34 / 33$ & $\begin{array}{c}\mathrm{T}: 55.80 \\
\pm 9.30 \\
\mathrm{C}: 56.40 \\
\pm 9.52 \\
\end{array}$ & $40 / 27$ & $|-| \mid$ & N.A. & N.A. & $\begin{array}{l}125 I+G C \\
(N A) / G C\end{array}$ & 42 days \\
\hline $\begin{array}{l}\text { Xianghua } \\
\text { Lin, } 2016 \\
{[24]}\end{array}$ & RCTs & $\begin{array}{l}\text { J Medical } \\
\text { Forum }\end{array}$ & 20/19 & $42-79$ & $21 / 18$ & $|-| \mid$ & $0.8-3.0$ & $\begin{array}{c}\text { P: } 26 \text {, } \\
\text { Central: } \\
13\end{array}$ & $\begin{array}{c}125 \mid+G C \\
(80-110 \text { Gy }) / \\
\text { GC }\end{array}$ & 6 months \\
\hline
\end{tabular}

$T$-treatment group, C-control group, TP-taxol + cisplatin, GC-gemcitabine + cisplatin, ${ }^{125}$ - iodine-125, CT-computed tomography, P-peripheral, N.A. - not available

Nine studies [11-14, 20-24] reported complications after ${ }^{125} \mathrm{I}$ implantation. There was a statistical heterogeneity among the results of each study $\left(I^{2}>50 \%, p<0.1\right)$. A meta-analysis using random effect model showed that the incidence of bleeding and pneumothorax was $0.14 \%$ (95\% CI: $0.07-0.21 \%$ ) and $0.19 \%$ (95\% CI: 0.11-0.28\%), respectively. There was no statistical heterogeneity in the incidence of radiation-induced lung injury in each study $\left(I^{2}=8 \%, p=0.37\right)$, and the result was $0.00 \%$ (95\% CI: 0.00 $0.03 \%)$, using fixed-effect model (Figure 5).

\section{Comparison of efficacy of ${ }^{125}$ I seeds implantation combined with chemotherapy and chemotherapy alone in the treatment of I-II NSCLC}

Two studies $[23,24]$ compared the efficacy of ${ }^{125} \mathrm{I}$ seeds implantation combined with chemotherapy and chemotherapy alone for early NSCLC. Compared with chemotherapy alone, ${ }^{125} \mathrm{I}$ seeds combined with chemotherapy could improve short-term LCR $(\mathrm{RR}=1.34)(95 \%$ CI: $1.09-1.65 \%, p=0.005)$ and short-term effective rate $(\mathrm{RR}=1.49)(95 \% \mathrm{CI}: 1.14-1.96 \%, p=0.0035)$.

\section{Publishing bias}

The results showed that no significant publication bias existed for the 1-, 2-, and 3-year survival rates $(\mathrm{t}=0.646,0.104$, and 0.296 , respectively, $p=0.554,0.922$, and 0.795 , respectively), and for the incidence of bleeding, pneumothorax, and radiation lung injury $(\mathrm{t}=0.521$, 0.640 , and 1.632 , respectively, $p=0.618,0.543$, and 0.164 , respectively). 
Table 2. Outcomes of the included studies

\begin{tabular}{|c|c|c|c|}
\hline $\begin{array}{l}\text { Study, year } \\
\text { [ref.] }\end{array}$ & Overall survival & Efficacy (based on CT) & $\begin{array}{l}\text { Adverse effect (bleeding/pneu- } \\
\text { mothorax/radiation lung injury) }\end{array}$ \\
\hline $\begin{array}{l}\text { Jiakai Li, } 2013 \\
\text { [11] }\end{array}$ & $\begin{array}{c}1-y: 95.8 \% \\
2-y: 78 \% \\
3-y: 55 \% \\
\text { Median survival time: } \\
38 \text { months (8-46) }\end{array}$ & $\begin{array}{l}\text { At the end of follow-up period: } \\
\qquad \text { CR: } 8 \\
\text { PR: } 10 \\
\text { SD: } 4 \\
\text { PD: } 6\end{array}$ & $4 / 3 / 0$ \\
\hline $\begin{array}{l}\text { Bin Huo, } 2017 \\
{[12]}\end{array}$ & $\begin{array}{l}1-y: 100 \% \\
2-y: 91.7 \% \\
3-y: 72.9 \%\end{array}$ & $\begin{array}{l}\text { y LC: } 100 \% \\
\text { y LC: } 95.2 \% \\
\text { y LC: } 95.2 \%\end{array}$ & $8 / 10 / 2$ \\
\hline $\begin{array}{l}\text { Jingkui Yang, } \\
2014 \text { [13] }\end{array}$ & $\begin{array}{l}1-y: 95.8 \% \\
2-y: 81.3 \% \\
5-y: 56.3 \%\end{array}$ & $\begin{array}{c}\text { 1-y LC: } 85 \% \\
\text { (based on PET-CT) }\end{array}$ & $8 / 12 / 0$ \\
\hline $\begin{array}{l}\text { Mingyao Ke, } \\
2011[14]\end{array}$ & $\begin{array}{l}1-y: 60 \% \\
2-y: 54 \% \\
3-y: 50 \% \\
4-y: 33 \%\end{array}$ & $\begin{array}{l}\text { 1-y LC: } 69 \% \\
\text { 2-y LC: } 58 \% \\
\text { 3-y LC: } 36 \% \\
\text { 4-y LC: } 11 \%\end{array}$ & $1 / 4 / 1$ \\
\hline $\begin{array}{l}\text { Jingkui Yang, } \\
2014 \text { [20] }\end{array}$ & $\begin{array}{l}1-y: 94.4 \% \\
2-y: 72.7 \% \\
3-y: 66.7 \% \\
5-y: 55.6 \%\end{array}$ & 6 months after implantation: CR: 7, PR: 9, SD: 2, PD: 0 & $3 / 6 / 0$ \\
\hline $\begin{array}{l}\text { Hua Cheng, } \\
2019 \text { [21] }\end{array}$ & $\begin{array}{l}1-y: 96.1 \% \\
2-y: 80.7 \% \\
3-y: 69.2 \%\end{array}$ & $\begin{array}{c}6 \text { months after implantation: CR: } 10, \text { PR: } 12, \text { SD: } 4 \text {, } \\
\text { PD: } 0 \\
1-y \text { LC: } 84.6 \%\end{array}$ & $4 / 3 / 0$ \\
\hline $\begin{array}{l}\text { Wei Fu, } 2019 \\
\text { [22] }\end{array}$ & $\begin{array}{l}\text { T: } 1-y: 100 \% \\
2-y: 92 \% \\
\text { C: } 1-y: 91.67 \% \\
2-y: 66.67 \%\end{array}$ & $\begin{array}{l}\text { T: short-term efficacy: CR: 4, PR: } 12 \text {, SD: 9, PD: } 0 \\
\text { y LC: } 100 \% \text {, 2-y LC: } 92 \% \\
\text { C: short-term efficacy: CR: 2, PR: } 12, \text { SD: 10, PD: } 0 \\
\text { y LC: } 95.83 \%, 2-y \text { LC: } 62.50 \%\end{array}$ & $1 / 2 / 0$ \\
\hline $\begin{array}{l}\text { Jianguo Yang, } \\
2018[23]\end{array}$ & N.A. & $\begin{array}{l}\text { T: short-term efficacy: CR: 10, PR: 17, SD: 2, PD: } 5 \\
\text { C: short-term efficacy: CR: 8, PR: 10, SD: 2, PD: } 13\end{array}$ & $1 / 2 / 0$ \\
\hline $\begin{array}{l}\text { Xianghua Lin, } \\
2016[24]\end{array}$ & N.A. & $\begin{array}{l}\text { T: } 6 \text { months after implantation: CR: 4, PR: 14, SD: } 2 \text {, } \\
\text { PD: } 0 \\
\begin{array}{c}\text { C: } 6 \text { months after implantation: CR: } 1 \text {, PR: 10, SD: } 4 \text {, } \\
\text { PD: } 4\end{array}\end{array}$ & $4 / 3 / 0$ \\
\hline
\end{tabular}

\section{Discussion}

Lung cancer is the leading cause of cancer-related mortality in adults globally, and its incidence continues to rise, with more than 1.8 million new cases and more than 1 million related deaths worldwide each year [25]. NSCLC is the most common type of lung cancer, accounting for $>80 \%$ of all lung cancer cases, of which $30 \%$ patients present the early-stage [26, 27]. For patients with operable early-stage NSCLC, complete surgical resection is preferable [28]. However, due to an increasing number of elderly patients, the existence of multiple post-operative complications, and personal suggestions, many patients are not eligible for surgical resection. Radiotherapy and chemotherapy are generally used as candidate options, which, however, cannot achieve cure, and may be accompanied by various complications. Therefore, for patients with early-stage NSCLC who are medically inoperable, an effective alternative is urgently needed.
Intra-operative ${ }^{125}$ I seeds brachytherapy has been proven to be an effective treatment option, which can be used as an alternative to external radiation therapy $[29,30]$. However, thoracotomy is required during intra-operative ${ }^{125} \mathrm{I}$ seeds implantation, and may increase hospital stay and financial burden of patient. Huo et al. [12] and Yang et al. [13] treated patients with ${ }^{125} \mathrm{I}$ seeds under CT guidance combined with a template. In these studies, the prescription doses were 120-160 Gy and 110 Gy, respectively. The results of Yang et al. showed that ${ }^{125}$ I seeds implantation had a high 1-year LCR (0.95) and survival rate (1 year $0.96,2$ years $-0.81,5$ years -0.56 ) for early-stage NSCLC. Nevertheless, because the guidelines recommend SBRT as the first choice of treatment for patients with early-stage NSCLC who cannot be resected or decline surgery, there are few studies on the application of ${ }^{125}$ I seeds in patients with early-stage NSCLC. Yet, in recent years, many scholars have confirmed that ${ }^{125}$ I seeds present good efficacy in 
Table 3. Quality assessment of randomized controlled trials

\begin{tabular}{lccccc}
\hline Study, year [ref.] & $\begin{array}{c}\text { Generation of random } \\
\text { sequences }\end{array}$ & $\begin{array}{c}\text { Allocation } \\
\text { concealment }\end{array}$ & Blind method & Withdrawal & Total \\
\hline Wei Fu, 2019 [22] & 2 & 1 & 0 & 1 & 4 \\
\hline Jianguo Yang, 2018 [23] & 2 & 1 & 0 & 1 & 4 \\
\hline Xianghua Lin, 2016 [24] & 0 & 0 & 0 & 1 & 1
\end{tabular}

Table 4. Quality assessment of single-arm studies

\begin{tabular}{|c|c|c|c|c|c|c|c|c|}
\hline Study, year [ref.] & $\begin{array}{l}\text { Represen- } \\
\text { tativeness }^{\mathrm{a}}\end{array}$ & $\begin{array}{l}\text { Selection } \\
\text { of non- } \\
\text { exposed }^{b}\end{array}$ & $\begin{array}{c}\text { Ascertain- } \\
\text { ment } \\
\text { of expo- } \\
\text { sure }^{c}\end{array}$ & $\begin{array}{l}\text { Incident } \\
\text { disease }^{d}\end{array}$ & $\begin{array}{l}\text { Compa } \\
\text { rabilitye }\end{array}$ & $\begin{array}{l}\text { Assess- } \\
\text { ment } \\
\text { of out- } \\
\text { come }^{f}\end{array}$ & $\begin{array}{l}\text { Length } \\
\text { of follow- } \\
\text { upg }\end{array}$ & $\begin{array}{c}\text { Adequacy } \\
\text { of follow- } \\
\text { up }^{h}\end{array}$ \\
\hline Jiakai Li, 2013 [11] & B & C & A & A & C & $\mathrm{B}$ & A & B \\
\hline Bin Huo, 2017 [12] & A & C & A & A & C & B & A & B \\
\hline Jingkui Yang, 2014 [13] & A & $\mathrm{C}$ & A & A & $C$ & $\mathrm{~B}$ & A & $\mathrm{D}$ \\
\hline Mingyao Ke, 2011 [14] & A & C & A & A & $\mathrm{C}$ & $B$ & A & A \\
\hline Jingkui Yang, 2014 [20] & A & C & A & A & C & $B$ & A & D \\
\hline Hua Cheng, 2019 [21] & A & C & $A$ & A & C & B & $A$ & $A$ \\
\hline
\end{tabular}

${ }^{a} A$ : truly representative, $B$ : somewhat representative, $C$ : selected group, $D:$ no description of the derivation of the cohort, ${ }^{b} A: d r a w n$ from the same community as the exposed, B: drawn from a different source, $C$ : no description of the derivation of the non-exposed, ${ }^{C} A$ : secure record, B: structured interview, $C$ : written self-report, $D$ : no description, ${ }^{d}$ Demonstration that the outcome of interest was not present at start of study: $A$ yes, $B:$ no, ${ }^{e} A$ : study controls for demographics/comorbidities, $B$ : study controls for any additional factor (e.g., age, severity of illness), C: not done; f A: independent or blind assessment, B: record linkage, C: self-report, D: no description, 9 Long enough for outcomes to occur? A: yes, B: no, ${ }^{h}$ A: complete follow-up, B: subjects lost to follow-up was unlikely to introduce bias, $C$ : follow-up rate of $90 \%$ or lower, D: no statement

the treatment of unresectable early-stage NSCLC, which is equivalent to SBRT. However, currently, the research quality is variable and practically inadequate, with limited sample size and evidence-based medical studies.

To our knowledge, the present study presented the first systematic review and meta-analysis of the available literature on ${ }^{125}$ I seeds implantation alone for inoperable early-stage NSCLC. Our research results showed that ${ }^{125} \mathrm{I}$ seeds implantation had a high LCR ( 1 year - 0.96, 2 years - 0.94, 3 years - 0.95) and survival rate $(1$ year -0.98 , 2 years -0.83 ; 3 years -0.65 ) for early-stage NSCLC. Because most of the patients included in this meta-analysis had peripheral lung cancer, we compared the results with the efficacy of SBRT for peripheral NSCLC. The Radiation Therapy Oncology Group (RTOG) 0236 [31] trial included 55 patients (T1 - 44 patients, T2 - 11 patients) with SBRT-treated inoperable early-stage peripheral NSCLC (T1-2N0M0), who received prescription dose of $54 \mathrm{~Gy} / 3 \mathrm{fx}$., with a median follow-up of 34.4 months (range, 4.8-49.9 months). The results showed that the 3-year primary tumor control rate was $97.6 \%$ (95\% CI: $84.3-99.7 \%)$, the 3-year survival rate was 55.8\% (95\% CI: 41.6-67.9\%), and the median survival was 48.1 months. Ball et al. [32] consisted of 66 patients (47 cases in T stage 1 and 19 cases in $\mathrm{T}$ stage 2) with peripheral early-stage NSCLC. Treatment consisted of three fractions of 18 Gy each (total, 54 Gy) or four fractions of 12 Gy each (total, $48 \mathrm{~Gy}$ ). The results showed that the 2-year LCR and survival rates reached $89 \%$ (95\% CI: $81-98 \%$ ) and 77\% (95\% CI: $67-88 \%$ ), respectively. Shibamoto et al. [33] used SBRT to treat 180 patients with early-stage NSCLC. Of these cases, 4, 124, and 52 patients received isocenter doses of $44 \mathrm{~Gy}, 48 \mathrm{~Gy}$, and $52 \mathrm{~Gy}$, respectively. The 3-year survival rate and LCR for peripheral NSCLC were $71 \%$ and $85 \%$, respectively. This meta-analysis showed that ${ }^{125} \mathrm{I}$ seeds implantation was virtually equivalent to SBRT in the treatment of inoperable peripheral early-stage NSCLC reported by scholars in recent years.

Stereotactic body radiotherapy is a method of delivering a high-dose of external beam radiotherapy to tumor targets very precisely, in a small number of fractions, and with high levels of targeting accuracy. The reason why ${ }^{125}$ I obtains a favorable effect may be related to its unique radiophysics and radiobiology characteristics. The dose distribution after seeds implantation decreases inversely according to the square of distance of the radioactive seeds. As the distance increases, the dose outside the target volume rapidly declines, thereby substantially increasing the dose in the target area as well as avoiding the occurrence of radioactive damage to vital tissues and organs around the target. Kim et al. [34] showed that ${ }^{125}$ I seeds could directly break single- and double-stranded DNA of tumor cells through sustained release of lowdose $\gamma$-rays, causing tumor cell damage. Because tumor cells in M and G2 phases are sensitive to radiation and other tumor cells in quiescent phase are relatively resistant to radiation, it may restore the proliferative ability after conventional external radiotherapy and SBRT due to their intermittent irradiation [35]. However, the radioactive ${ }^{125} \mathrm{I}$ seeds can kill tumor cells continuously, and after a sufficient half-life period, a certain accumulated dose can lead to a complete loss of proliferative potential of the tumor cells. Conversely, y-ray can reduce the oxygen increase ratio of tumor cells. In other words, the dependence of radiation on killing tumor cells to oxygen is reduced; therefore, ${ }^{125} \mathrm{I}$ seeds overcome the radiation resistance of hypoxic cells, thus continuously damaging tumor stem cells and causing death of tumor cells [36]. 
A Study

Events Total

Jiakai Li 2013
Hua Cheng 2019
Wei Fu 2019
Jingkui Yang 2014
Bin Huo 2017
Jingkui Yang* 2014

Fixed effect model

Random effects model Heterogeneity: $I^{2}=14 \%, \tau^{2}=0.0016, p=0.32$

B

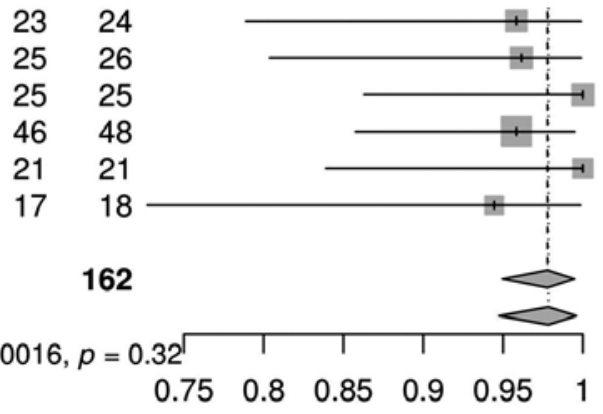

Study

Events Total
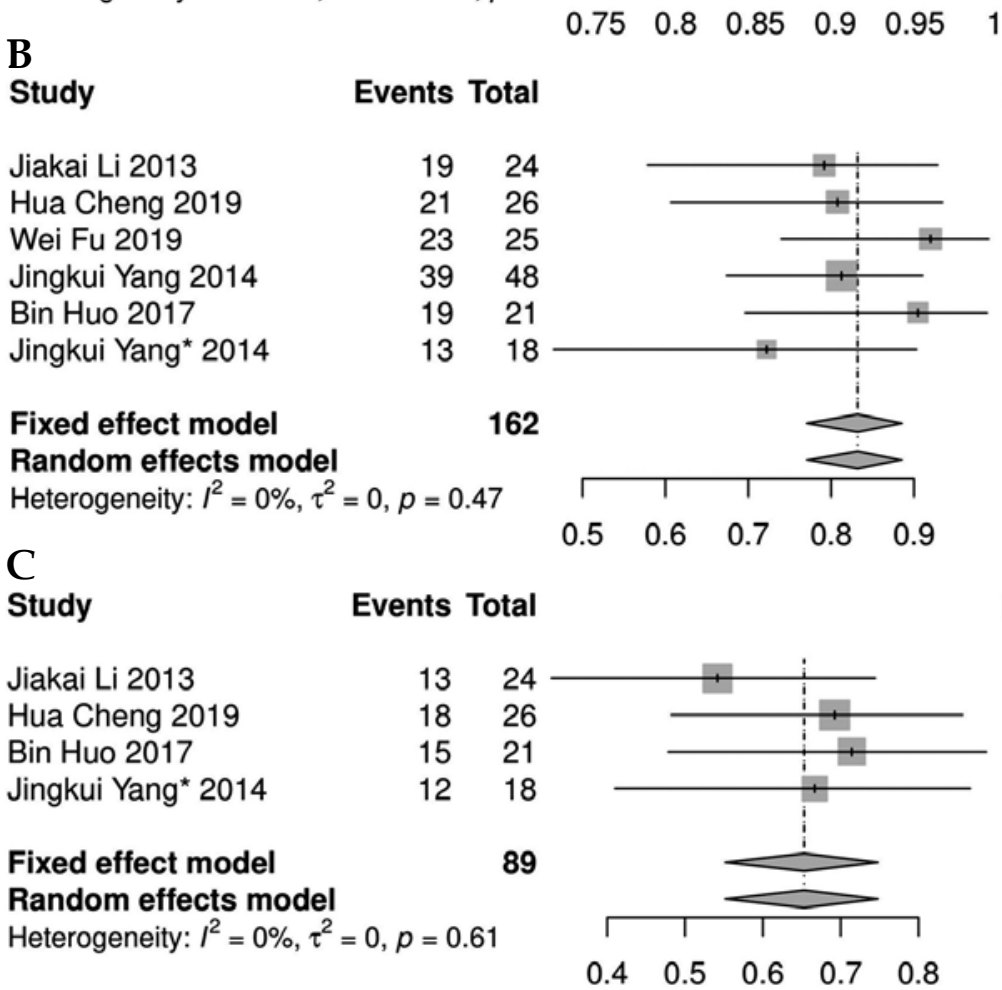

Jiakai Li 2013

Hua Cheng 2019

Wei Fu 2019

Bin Huo 2017

Jingkui Yang 2014

\section{Fixed effect model \\ Random effects model}

Heterogeneity: $I^{2}=0 \%, \tau^{2}=0, p=0.47$

\section{Jiakai Li 2013}

Hua Cheng 2019

Bin Huo 2017

$\begin{array}{lllll}0.4 & 0.5 & 0.6 & 0.7 & 0.8\end{array}$
Proportion $\quad 95 \%-\mathrm{Cl} \begin{gathered}\text { Weight } \\ \text { (fixed) }\end{gathered} \begin{gathered}\text { Weight } \\ \text { (random) }\end{gathered}$

$0.96[0.79 ; 1.00] \quad 14.8 \% \quad 15.3 \%$

$0.96[0.80 ; 1.00] \quad 16.0 \% \quad 16.4 \%$

$1.00[0.86 ; 1.00] \quad 15.4 \% \quad 15.8 \%$

$0.96[0.86 ; 0.99] \quad 29.6 \% \quad 27.1 \%$

$1.00[0.84 ; 1.00] 13.0 \% \quad 13.6 \%$

$0.94[0.73 ; 1.00] \quad 11.1 \% \quad 11.8 \%$

$0.98[0.95 ; 0.99] 100.0 \%$

$0.98[0.95 ; 1.00] \quad-\quad 100.0 \%$
Proportion Weight Weight

(fixed) (random)

$0.79[0.58 ; 0.93] \quad 14.8 \% \quad 14.8 \%$

$0.81[0.61 ; 0.93] \quad 16.0 \% \quad 16.0 \%$

$0.92[0.74 ; 0.99] \quad 15.4 \% \quad 15.4 \%$

$0.81[0.67 ; 0.91] \quad 29.6 \% \quad 29.6 \%$

$0.90[0.70 ; 0.99] \quad 13.0 \% \quad 13.0 \%$

$0.72[0.47 ; 0.90] \quad 11.1 \% \quad 11.1 \%$

$0.83[0.77 ; 0.89] 100.0 \%$ $0.83[0.77 ; 0.89] \quad--100.0 \%$

Weight Weight

Proportion 95\%-Cl (fixed) (random)

$\begin{array}{rrr}0.54[0.33 ; 0.74] & 27.0 \% & 27.0 \% \\ 0.69[0.48 ; 0.86] & 29.2 \% & 29.2 \% \\ 0.71[0.48 ; 0.89] & 23.6 \% & 23.6 \% \\ 0.67[0.41 ; 0.87] & 20.2 \% & 20.2 \% \\ & & \\ 0.65[0.55 ; 0.75] & 100.0 \% & -- \\ 0.65[0.55 ; 0.75] & -- & \mathbf{1 0 0 . 0 \%}\end{array}$

$0.54[0.33 ; 0.74] \quad 27.0 \% \quad 27.0 \%$

$29.2 \%$

$3.6 \%$

$100.0 \%$

Fig. 2. Forest plot of 1-, 2-, and 3-year survival rates (A, B, and C, respectively)

Here, we performed sub-group analysis according to the prescribed dose, which further proved that higher prescription dose ( $>120 \mathrm{~Gy}$ ) was associated with a better short-term effective rate and 1-year LCR. In a study by Huo et al. [12], the prescribed dose of seeds was 120-160 Gy, and both short-term effective rate and 1-year LCR were $100 \%$. In a research by Ke et al. [14], the prescription dose of seeds was 140 to $160 \mathrm{~Gy}$, and its short-term effective rate reached $100 \%$. Unfortunately, the improvement in short-term effective rate and 1-year LCR have not improved patients' long-term survival. Due to the limited number of studies currently available, there are few studies reporting long-term LCRs and survival. It is inconclusive whether prescription doses $>120$ Gy can improve patient survival; however, sub-groups analysis of the $1-, 2-$, and 3-year survival rates found that prescription doses $>120$ Gy have a tendency to improve patient survival.

There were 3 RCTs on chemotherapy vs. ${ }^{125} \mathrm{I}$ seeds alone, or ${ }^{125}$ I seeds plus chemotherapy for early NSCLC. Fu et al. [22] found that despite no significant difference in short-term efficacy between ${ }^{125}$ I seeds group and chemotherapy group, the 2-year LCR and survival rate of ${ }^{125}$ I seeds group were higher than those of chemotherapy group. Yang et al. [23] and Lin et al. [24] reported that compared with chemotherapy group, the ${ }^{125}$ I seeds combined with chemotherapy can significantly improve short-term efficacy without increasing toxicity. Unfortunately, neither study reported long-term survival. Whether ${ }^{125} \mathrm{I}$ seeds combined with chemotherapy would improve patient's survival needs to be further confirmed by future research. In addition, according to the 2020 NCCN guidelines [37], for patients with inoperable high-risk stage IB-IIB NSCLC or with T1-2N1M0 NSCLC, systemic chemotherapy has been recommended as an adjuvant treatment, but chemotherapy has not been regarded as sole treatment option for these patients. We acknowledge this as a limitation of these studies as well as our meta-analysis. More studies comparing external beam radiotherapy or SBRT to ${ }^{125}$ I seeds brachytherapy for the treatment of early-stage NSCLC are still needed in the future. 


\section{A} Study

Events Total

Proportion

Weight Weight

Hua Cheng 2019

Jingkui Yang 2014

Xianghua Yang 2016

Jiakai Li 2013

Jingkui Yang* 2014

Mingyao Ke 2011

Bin Huo 2017

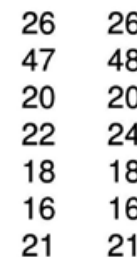

$21 \quad 21$

Fixed effect model

Random effects model

Heterogeneity: $I^{2}=22 \%, \tau^{2}=0.0030, p=0.26$

\section{3}

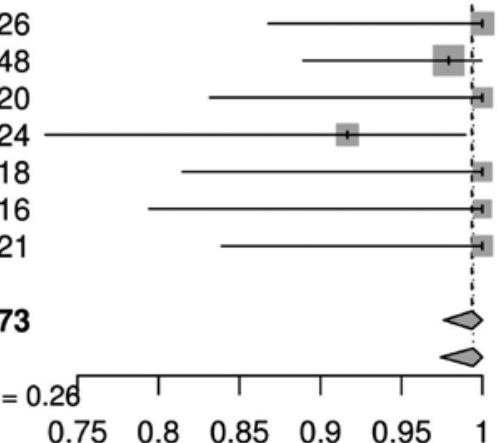

B

Study

\section{Events Total}

\section{Proportion}

$\begin{array}{rr}1.00[0.87 ; 1.00] & 15.0 \% \\ 0.98[0.89 ; 1.00] & 27.7 \% \\ 1.00[0.83 ; 1.00] & 11.6 \% \\ 0.92[0.73 ; 0.99] & 13.9 \% \\ 1.00[0.81 ; 1.00] & 10.4 \% \\ 1.00[0.79 ; 1.00] & 9.2 \% \\ 1.00[0.84 ; 1.00] & 12.1 \% \\ & \\ 0.99[0.98 ; 1.00] & 100.0 \% \\ \mathbf{0 . 9 9}[0.97 ; \mathbf{1 . 0 0}] & --\end{array}$

$15.2 \%$

$23.4 \%$

$12.4 \%$

$14.3 \%$

$11.4 \%$

$10.3 \%$

$12.9 \%$

\section{$0.99[0.97 ; 1.00]$}

$100.0 \%$

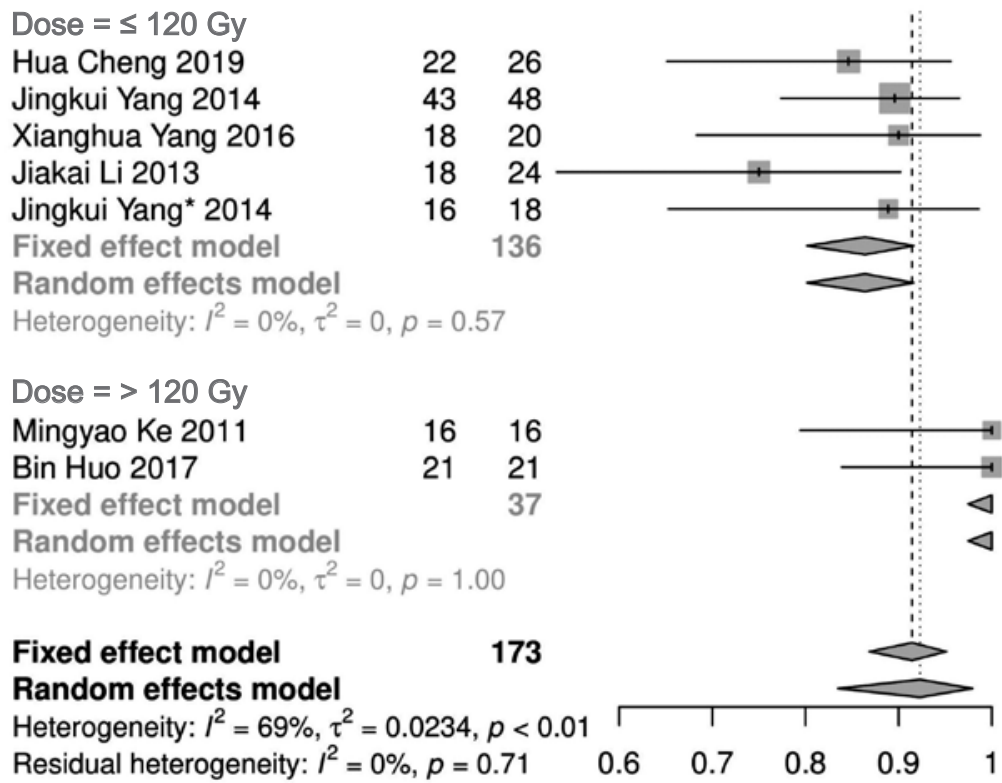

$\begin{array}{rrr}0.85[0.65 ; 0.96] & 15.0 \% & 14.9 \% \\ 0.90[0.77 ; 0.97] & 27.7 \% & 17.2 \% \\ 0.90[0.68 ; 0.99] & 11.6 \% & 13.7 \% \\ 0.75[0.53 ; 0.90] & 13.9 \% & 14.5 \% \\ 0.89[0.65 ; 0.99] & 10.4 \% & 13.2 \% \\ 0.86[0.80 ; 0.92] & 78.6 \% & -- \\ 0.86[0.80 ; 0.92] & -- & 73.5 \%\end{array}$

$1.00[0.79 ; 1.00] \quad 9.2 \%$

$1.00[0.84 ; 1.00] \quad 12.1 \%$

$1.00[0.97 ; 1.00] 21.4 \%$

$12.6 \%$

$13.9 \%$

$1.00[0.97 ; 1.00] \quad--\quad 26.5 \%$

$0.91[0.87 ; 0.95] 100.0 \%$ $0.92[0.83 ; 0.98] \quad-\quad 100.0 \%$

Fig. 3. Forest plot of short-term local control rate and effective rate (A and $\mathbf{B}$, respectively)

Although SBRT is a precision radiotherapy technique, its damage to normal tissues should not be taken lightly. For peripheral lung cancer, chest wall pain is an important adverse reaction after SBRT treatment, which often occurs at 6 to 9 months after treatment, with an incidence rate of $6-39 \%$, followed by a pain grade 3 or higher, occurring in approximately $2 \%$ of patients [38]. In a study of Stephans et al. [39], the rates of chest wall and pulmonary toxicity (any grade) with SBRT dose of $60 \mathrm{~Gy} / 3 \mathrm{fx}$. for peripheral lung cancer were $23.7 \%$ and $5.0 \%$, respectively. Moreover, the rates of grade 3 or higher for chest wall and pulmonary toxicity were approximately $0.72 \%$ and $1.4 \%$, respectively. In a research of Singh et al. [40], 98 patients with peripheral stage I-II NSCLC were randomized into $30 \mathrm{~Gy} / 1 \mathrm{fx}$. and $60 \mathrm{~Gy} / 3 \mathrm{fx}$. groups, respectively. Thoracic grade 3 adverse events were experienced by $8(16 \%)$ patients in $30 \mathrm{~Gy} / 1 \mathrm{fx}$. group, and by $6(12 \%)$ patients in $60 \mathrm{~Gy} / 3 \mathrm{fx}$. group. Our results showed that bleeding and pneumothorax caused by seeds implantation occurred in $0.14 \%$ and $0.19 \%$ of patients, respectively, and all were al- leviated after symptomatic treatment. During a follow-up period, there were 2 cases of grade 1 pulmonary fibrosis reported by Huo et al. [12], and 1 case of grade 1 local radiation pneumonitis reported by Ke et al. [14]. There were no treatment-related adverse reactions of grade 3 or higher and deaths in all studies. Compared with SBRT, adverse events caused by ${ }^{125}$ I were significantly reduced. ${ }^{125}$ I seeds implantation is an internal radiotherapy, and in other words, the radiation kills tumor cells from the inside of the target area. By contrast, SBRT can also ensure quick reduction of dose at the edge of the target area, thereby reducing the radiation dose of surrounding vital tissues. However, it is still a type of external radiotherapy, with its radiation inevitably passing through normal tissues, causing certain radiation damage, especially in central lung cancer patients.

This study has several limitations. First, since NCCN and ESMO have recommended SBRT as the preferable treatment strategy for inoperable early NSCLC, there is a small number of studies on the application of ${ }^{125} \mathrm{I}$ seeds 
A Study Events Total

Proportion

Weight Weight

Time $=1$ year

Hua Cheng 2019

Wei Fu 2019

Jingkui Yang 2014

Bin Huo 2017

$\begin{array}{lr}22 & 26 \\ 25 & 25 \\ 41 & 48 \\ 21 & 21 \\ & 120\end{array}$

26
25
48
21
20

Random effects model

Heterogeneity: $I^{2}=83 \%, \tau^{2}=0.0428, p<0.01$

Time $=2$ year

Wei Fu 2019

$23 \quad 25$

Bin Huo 2017

$20 \quad 21$

Fixed effect model 46

Random effects model

Heterogeneity: $I^{2}=0 \%, \tau^{2}=0, p=0.65$

Time $=3$ year

Bin Huo 2017

Fixed effect model

$20 \quad 21$

Random effects model

Heterogeneity: not applicable

\section{Fixed effect model}

Random effects model

Heterogeneity: $I^{2}=67 \%, \tau^{2}=0.0192, p<0.01$

Residual heterogeneity: $I^{2}=78 \%, p<0.01$

21

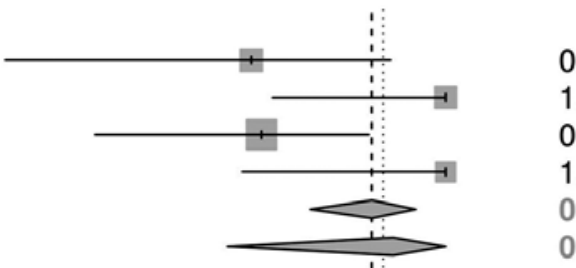

$0.85[0.65 ; 0.96] 13.9 \%$

$1.00[0.86 ; 1.00] 13.4 \%$

$0.85[0.72 ; 0.94] 25.7 \%$

$1.00[0.84 ; 1.00] 11.2 \%$

$0.94[0.89 ; 0.98] \quad 64.2 \%$

$0.96[0.83 ; 1.00] \quad--$

B

Study

Events Total

$0.92[0.74 ; 0.99] \quad 13.4 \%$

$14.2 \%$

$0.95[0.76 ; 1.00] \quad 11.2 \%$

$13.4 \%$

$0.94[0.85 ; 0.99] \quad 24.6 \%$

$--$

$0.94[0.85 ; 0.99] \quad-$

$27.6 \%$

$0.95[0.76 ; 1.00] \quad 11.2 \%$

$13.4 \%$

$0.95[0.82 ; 1.00] 11.2 \%$

$13.4 \%$

$0.95[0.82 ; 1.00] \quad--\quad 13.4 \%$

$0.94[0.90 ; 0.97] 100.0 \%$

$0.95[0.88 ; 0.99] \quad-\quad 100.0 \%$

Dose $=\leqq 120$ Gy

Hua Cheng 2019

Jingkui Yang 2014

Fixed effect model

Random effects model

Heterogeneity: $l^{2}=0 \%, \tau^{2}=0, p=0.93$

Dose $=>120 \mathrm{~Gy}$

Bin Huo 2017

Fixed effect model

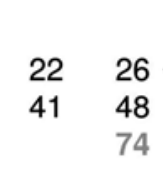

$21 \quad 21$

21

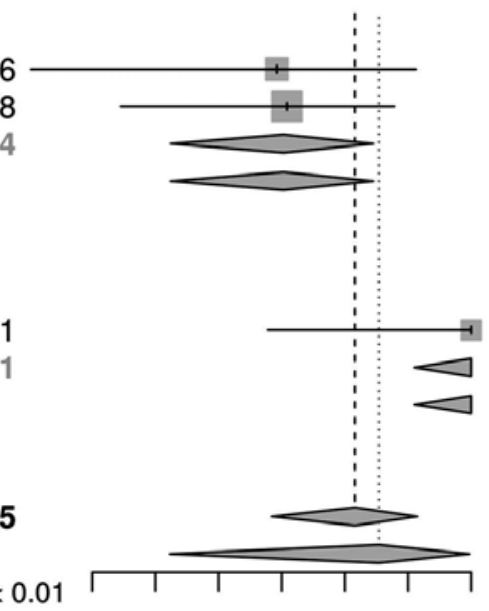

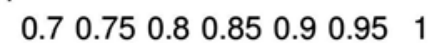

$\begin{array}{rrr}0.85[0.65 ; 0.96] & 27.4 \% & 32.7 \% \\ 0.85[0.72 ; 0.94] & 50.5 \% & 36.3 \% \\ 0.85[0.76 ; 0.92] & 77.9 \% & -- \\ 0.85[0.76 ; 0.92] & -- & 68.9 \%\end{array}$

$1.00[0.84 ; 1.00] 22.1 \%$

$1.00[0.95 ; 1.00] \quad 22.1 \%$

$1.00[0.95 ; 1.00] \quad--$

$31.1 \%$

$31.1 \%$

$0.91[0.84 ; 0.96] 100.0 \%$ $0.93[0.76 ; 1.00] \quad--100.0 \%$

\section{Random effects model}

Heterogeneity: $I^{2}=81 \%, \tau^{2}=0.0350, p<0.01$

Residual heterogeneity: $I^{2}=0 \%, p=0.93$

Fig. 4. Forest plot of 1-, 2-, and 3-year local control rates (A) and sub-group analysis of 1-year local control rate (B)

implantation in early-stage NSCLC. Second, the tumor location was not clear in some of the studies included in our meta-analysis. Since most of the patients had peripheral lung cancer, we compared the efficacy and toxicity of ${ }^{125} \mathrm{I}$ seeds brachytherapy with those of SBRT only for peripheral NSCLC. Finally, in 3 RCTs included in this meta-analysis, chemotherapy alone (not radiation therapy/SBRT) was compared to ${ }^{125}$ I seeds brachytherapy or ${ }^{125}$ I plus chemotherapy. Therefore, more studies comparing radiation therapy or SBRT with brachytherapy for the treatment of early-stage NSCLC are needed in the future.

\section{Conclusions}

In conclusion, the results of our study indicate that ${ }^{125}$ I seeds implantation is a safe and effective option for the treatment of inoperable early-stage NSCLC. Moreover, higher prescribed dose (>120 Gy) is associated with a better short-term effective rate and 1-year LCR. ${ }^{125} \mathrm{I}$ 
A Study

Jiakai Li 2013

Hua Cheng 2019

Wei Fu 2019

Jianguo Yang 2018

Jingkui Yang 2014

Xianghua Yang 2016

Bin Huo 2017

Mingyao Ke 2011

Jingkui Yang 2014

Fixed effect model

Random effects model

Heterogeneity: $I^{2}=49 \%, \tau^{2}=0.0095, p=0.04$

B
Jiakai Li 2013
Hua Cheng 2019
Wei Fu 2019
Jianguo Yang 2018
Jingkui Yang 2014
Xianghua Yang 2016
Bin Huo 2017
Mingyao Ke 2011
Jingkui Yang* 2014

Fixed effect model

Random effects model
Events Total

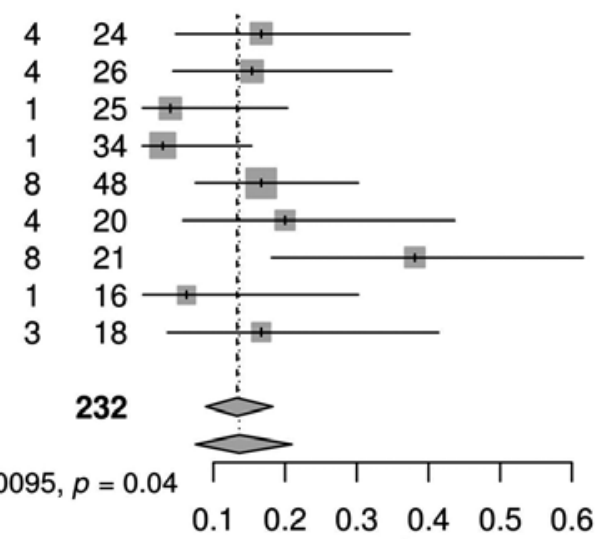

Weight Weight

Proportion 95\%-Cl (fixed) (random)

$0.17[0.05 ; 0.37] \quad 10.4 \% \quad 11.0 \%$

$0.15[0.04 ; 0.35] \quad 11.2 \% \quad 11.5 \%$

$0.04[0.00 ; 0.20] \quad 10.8 \% \quad 11.2 \%$

$0.03[0.00 ; 0.15] \quad 14.6 \% \quad 13.0 \%$

$0.17[0.07 ; 0.30] \quad 20.5 \% \quad 14.8 \%$

$0.20[0.06 ; 0.44] \quad 8.7 \% \quad 10.0 \%$

$0.38[0.18 ; 0.62] \quad 9.1 \% \quad 10.3 \%$

$0.06[0.00 ; 0.30] \quad 7.0 \% \quad 8.8 \%$

$0.17[0.04 ; 0.41] \quad 7.8 \% \quad 9.4 \%$

$\begin{array}{llr}0.13[0.09 ; 0.18] & 100.0 \% & -- \\ 0.14[0.07 ; 0.21] & -- & 100.0 \%\end{array}$

Weight Weight

Events Total

Proportion 95\%-Cl (fixed) (random)

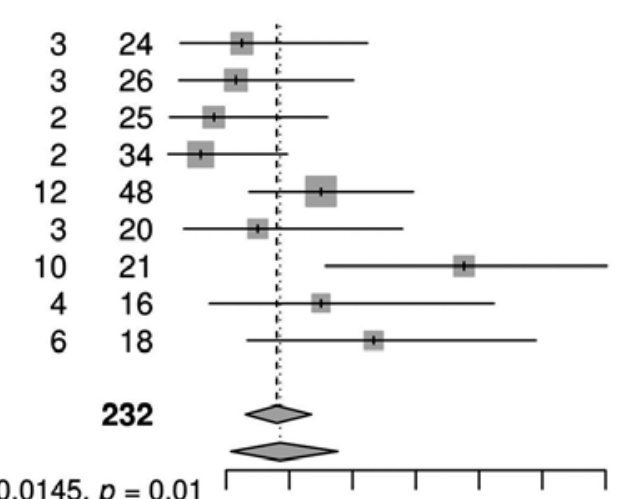

$0.12[0.03 ; 0.32] \quad 10.4 \% \quad 11.1 \%$

$0.12[0.02 ; 0.30] \quad 11.2 \% \quad 11.4 \%$

$0.08[0.01 ; 0.26] \quad 10.8 \% \quad 11.3 \%$

$0.06[0.01 ; 0.20] \quad 14.6 \% \quad 12.6 \%$

$0.25[0.14 ; 0.40] \quad 20.5 \% \quad 13.9 \%$

$0.15[0.03 ; 0.38] \quad 8.7 \% \quad 10.3 \%$

$0.48[0.26 ; 0.70] \quad 9.1 \% \quad 10.5 \%$

$0.25[0.07 ; 0.52] \quad 7.0 \% \quad 9.2 \%$

$0.33[0.13 ; 0.59] \quad 7.8 \% \quad 9.8 \%$

$0.18[0.13 ; 0.23] 100.0 \%$

$0.19[0.11 ; 0.28] \quad-\quad 100.0 \%$
C

Study

Hua Chen 2019

Bin Huo 2017

Jingkui Yang 2014

Xianghua Yang 2016

Jiakai Li 2013

Mingyao Ke 2011

Jingkui Yang* 2014

Fixed effect model

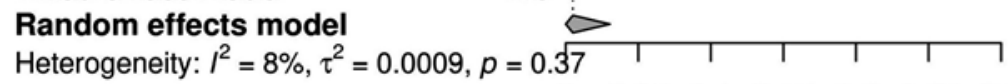

\section{Events Total}

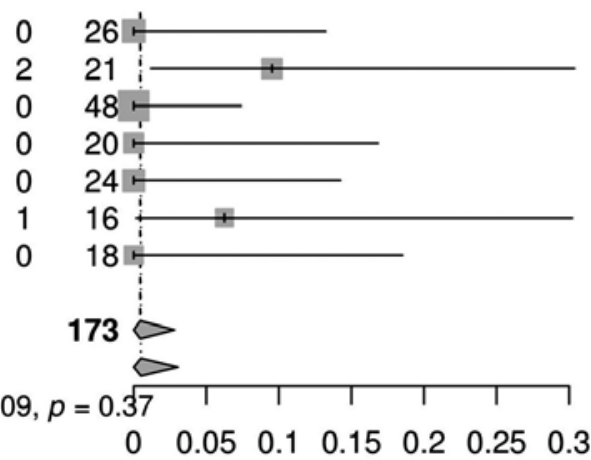

Weight Weight

Proportion 95\%-Cl (fixed) (random)

$0.00[0.00 ; 0.13] \quad 15.0 \% \quad 15.1 \%$

$0.10[0.01 ; 0.30] \quad 12.2 \% \quad 12.5 \%$

$0.00[0.00 ; 0.07] \quad 27.5 \% \quad 25.8 \%$

$0.00[0.00 ; 0.17] \quad 11.6 \% \quad 11.9 \%$

$0.00[0.00 ; 0.14] \quad 13.9 \% \quad 14.1 \%$

$0.06[0.00 ; 0.30] \quad 9.3 \% \quad 9.7 \%$

$0.00[0.00 ; 0.19] \quad 10.5 \% \quad 10.8 \%$

$0.00[0.00 ; 0.03] 100.0 \% \quad 100 \overline{\%}$

Fig. 5. Forest plot of incidence of bleeding, pneumothorax, and radiation lung injury (A, B, and C, respectively)

seeds combined with chemotherapy, as compared with chemotherapy alone, can improve short-term LCR and effective rate. The application of ${ }^{125} \mathrm{I}$ seeds implantation in the treatment of patients with inoperable early-stage non-small cell lung cancer still needs to be confirmed by further high-quality clinical research.

\section{Disclosure}

The authors report no conflict of interest.

\section{References}

1. Siegel RL, Miller KD, Jemal A. Cancer statistics, 2020. CA Cancer J Clin 2020; 70: 7-30.

2. Chen $\mathrm{W}$, Zheng R, Baade PD et al. Cancer statistics in China, 2015. CA Cancer J Clin 2016; 66: 115-132.

3. Torre LA, Bray F, Siegel RL et al. Global cancer statistics, 2012. CA Cancer J Clin 2015; 65: 87-108.

4. Scott W J, Howington J, Feigenberg $S$ et al. Treatment of non-small cell lung cancer stage I and stage II: ACCP evidence-based clinical practice guidelines (2nd edition). Chest 2007; 132: 234S-242S. 
5. Wisnivesky JP, Bonomi M, Henschke C et al. Radiation therapy for the treatment of unresected stage I-II non-small cell lung cancer. Chest 2005; 128: 1461-1467.

6. Nagata Y, Hiraoka M, Shibata T et al. Prospective trial of stereotactic body radiation therapy for both operable and inoperable T1N0M0 non-small cell lung cancer: Japan Clinical Oncology Group Study JCOG0403. Int I Radiat Oncol Biol Phys 2015; 93: 989-996.

7. Dupic G, Biau J, Molnar I et al. Significant correlation between overall survival and mean lung dose in lung stereotactic body radiation therapy (SBRT). Front Oncol 2020; 10: 1577.

8. Shu Z, Dong B, Shi L et al. Stereotactic body radiotherapy for elderly patients ( $\geq 75$ years) with early-stage non-small cell lung cancer. J Cancer Res Clin Oncol 2020; 146: 1263-1271.

9. Chen C, Wang W, Yu Z et al. Combination of computed tomography-guided iodine- 125 brachytherapy and bronchial arterial chemoembolization for locally advanced stage III non-small cell lung cancer after failure of concurrent chemoradiotherapy. Lung Cancer 2020; 146: 290-296.

10. Zhang W, Li J, Li R et al. Efficacy and safety of iodine- 125 radioactive seeds brachytherapy for advanced non-small cell lung cancer - a meta-analysis. Brachytherapy 2018; 17: 439-448.

11. Li JK, Yu M, Xiao Y et al. Computed tomography fluoroscopy guided percutaneous 125 I seed implantation for safe, effective and real time monitoring radiotherapy of inoperable stage T1-3N0M0 non-small cell lung cancer. Mol Clinl Oncol 2013; 1: 1019-1024.

12. Huo B, Huo XD, Wang L et al. CT and template-guided radioactive seed implantation for inoperable early stage non-small cell lung cancer. Chin J Radiol Med Prot 2017; 37: 500-504.

13. Yang JK, Lv JS, Yan WL et al. Analysis of curative effect of implantation of radioactive seeds on inoperable early-stage nonsmall cell lung cancer. Chin J Clin Oncol 2014; 17: 1111-1114.

14. Ke MY, Yong YZ, Luo BQ et al. Study of percutaneous 125I seeds implantation guided by $\mathrm{CT}$ in elderly patients of stage I peripheral non-small cell lung cancer. Chin J Radiat Oncol 2011; 20: 394-396.

15. Eisenhauer EA, Therasse P, Bogaerts J et al. New response evaluation criteria in solid tumours: revised RECIST guideline (version 1.1). Eur J Cancer 2009; 45: 228-247.

16. Jadad AR, Moore RA, Carroll D et al. Assessing the quality of reports of randomized clinical trials: Is blinding necessary? Control Clin Trials 1996; 17: 1-12.

17. Wells GA, Shea B, O'Connell D et al. The Newcastle-Ottawa Scale (NOS) for assessing the quality of nonrandomised studies in meta-analyses. Available: http://www.ohri.ca/ programs/clinical_epidemiology/oxford.asp.

18. Liu Q, Li W, Xue M et al. Diabetes mellitus and the risk of multidrug resistant tuberculosis: a meta-analysis. Sci Rep 2017; 24: 1090

19. Balduzzi S, Rücker G, Schwarzer G. How to perform a meta-analysis with R: a practical tutorial. Evid Based Ment Health 2019; 22: 153-160.

20. Yang JK, Huo XD, Yan WL et al. Effect of CT-guided125I seeds implant brachytherapy on early non-small cell lung cancer. Chin J Geriaty 2014; 33: 757-759.

21. Cheng H, Wu FM, Qin NN et al. Efficacy analysis of CT-guided brachytherapy with $125 \mathrm{I}$ seed implantation for non-operative early non-small cell lung cancer. World Latest Medicine Information 2019; 66: 220-222.

22. Fu W, Chen SX, Zhou QY et al. Clinical study of radioactive seeds in the treatment of inoperable early-stage non-small cell lung cancer. J Pract Radiol 2019; 35: 1311-1314, 1318.

23. Yang JG. Application effect of CT guided percutaneous implantation of iodine- 125 seed combined with GC chemotherapy on early-stage non-small cell lung cancer. Chin J Pract Med 2018; 45: 73-76.
24. Lin $\mathrm{XH}$, Shi J. Effects of combined 125 I seeds implantation and chemotherapy in early stage of non-small cell lung cancer. J Medical Forum 2016; 37: 60-64.

25. Torre LA, Bray F, Siegel RL et al. Global cancer statistics, 2012. CA Cancer J Clin 2015; 65: 87-108.

26. Midthun DE, Jett JR. Update on screening for lung cancer. Semin Respir Crit Care Med 2008; 29: 233-240.

27. Morgensztern D, Ng SH, Gao F et al. Trends in stage distribution for patients with non-small cell lung cancer: a National Cancer Database survey. J Thorac Oncol 2010; 5: 29-33.

28. Postmus PE, Kerr KM, Oudkerk M et al. Early and locally advanced non-small-cell lung cancer (NSCLC): ESMO Clinical Practice Guidelines for diagnosis, treatment and follow-up. Ann Oncol 2017; 28: iv1-iv21.

29. Lee W, Daly BD, DiPetrillo TA et al. Limited resection for non-small cell lung cancer: observed local control with implantation of I-125 brachy-therapy seeds. Ann Thorac Surg 2003; 75: 237-242.

30. Pisch J, Belsley SJ, Ashton R et al. Placement of $125 \mathrm{I}$ implants with the da Vinci robotic system after video-assisted thoracoscopic wedge resection: a feasibility study. Int J Radiat Oncol Biol Phys 2004; 60: 928-932.

31. Timmerman R, Paulus R, Galvin J et al. Stereotactic body radiation therapy for inoperable early stage lung cancer. JAMA 2010; 303: 1070-1076.

32. Ball D, Mai GT, Vinod S et al. Stereotactic ablative radiotherapy versus standard radiotherapy in stage I non-small-cell lung cancer (TROG 09.02 CHISEL): a phase 3, open-label, randomised controlled trial. Lancet Oncol 2019; 20: 494-503.

33. Shibamoto Y, Hashizume C, Baba F et al. Stereotactic body radiotherapy using a radiobiology-based regimen for stage I non-small cell lung cancer: a multicenter study. Cancer 2012; 118: 2078-2084.

34. Kim JH, Hilaris B. Iodine 125 source in interstitial tumor therapy. Clinical and biological considerations. Am J Roentgenol Radium Ther Nucl Med 1975; 123: 163-169.

35. Norbury CJ, Hickson ID. Cellular responses to DNA damage. Annu Rev Pharmacol Toxicol 2001; 41:367-401.

36. Hill RP, Bush RS. The effect of the continuous of fractionated irradiation on a murine sarcoma. Br J Radiol 1973; 46: 167-174.

37. Ettinger DS, Wood DE, Aggarwal C et al. NCCN guidelines insights: non-small cell lung cancer, version 1.2020. J Natl Compr Canc Netw 2019; 17: 1464-1472.

38. Stephans KL, Djemil T, Tendulkar RD et al. Prediction of chest wall toxicity from lung stereotactic body radiotherapy (SBRT). Int J Radiat Oncol Biol Phys 2012; 82: 974-980.

39. Stephans KL, Woody NM, Reddy CA et al. Tumor control and toxicity for common stereotactic body radiation therapy dose-fractionation regimens in stage I non-small cell lung cancer. Int J Radiat Oncol Biol Phys 2018; 100: 462-469.

40. Singh AK, Gomez-Suescun JA, Stephans KL et al. One versus three fractions of stereotactic body radiation therapy for peripheral stage I to II non-small cell lung cancer: a randomized, multi-institution, phase 2 trial. Int J Radiat Oncol Biol Phys 2019; 105: 752-759. 